\title{
A STUDY OF LYSINE OPERON ORGANIZATION IN BACILLUS SUBTILIS
}

Z. M. Aleksieva, T. N. Shevchenko, S. S. Malyuta

Institute of Molecular Biology and Genetics, Academy of

Sciences of the Ukrainian SSR, Kiev

S u m m a r y

The pBR322 plasmid was used for constructing $p L B 1$ plasmid carrying genes of Bacillus subtilis lysine biosynthesis. B. subtilis and E. coli strains (lysine-auxotrophs) are transformed. The plasmid is shown to complement both mutations in seven genes of lysine biosynthesis in E. coli cells and four mutations in $B$. subtilis. The size of DNA insertion, according to the elctrophoresis data, is $4,5 \cdot 10^{6}$.

1. Umbarger H. E. Amino acid biosynthesis and its regulation.-Annu. Rev. Biochem., 1978,47 , p. $533-606$.

2. Bachmann B.J., Low K. B. Linkage map of Escherichia coli K-12.-Microbiol. Revs., $1980,44, N 1$, p. $1-56$

3. Окунев О. В., Шевченко Т. Н., Малюта С. С. Клонирование фрагмента ДНК Ваcillus subtilis, содержащего гены биосинтеза лизина и рибофлавина.-Генетика, 1984,20, № 7 , c. $1061-1066$.

4. Экспресcия генов биосинтеза лизина Bacillus subtilis в клетках Escherichia coli/ Т. Н. Шевченко, О. В. Окунев, 3. М. Алексиева, С. С. Малюта.-Цитология и генетика, 1984,18 , № 1 , с. $58-74$.

5. Improvement of Escherichia coli strains overproducing lysine using recombinant DNA techniques / B. D. Beverend, A. M. Boitel, A. M. Deschamps et al.-Eur. J. Appl. Microbiol., $1982,15, \mathrm{~N} \mathrm{2}$, p. $227-231$.

Ин-т молекуляр. биологии и генетики

АН УССР, Киев

Получено 19.10 .84

УДК $577.112 .5: 578.841$

\section{АМИНОКИСЛОТНАЯ ПОСЛЕДОВАТЕЛЬНОСТЬ ФРАГМЕНТОВ ПОЛИПЕПТИДНОЙ ЦЕПИ ГРАНУЛИНА ВИРУСА ГРАНУЛЕЗА ОЗИМОЙ СОВКИ, AGROTIS SEGETUM}

\author{
Э. А. Козлов, Т. Л. Левитина, Н. В. Роднин, \\ В. М. Харченко, С. Б. Серебряный
}

В предыдущем сообшении [1] обсуждались результаты сравнительгого исследования физико-химических свойств полиэдрина вируса ядерного полиэдроза (ВЯП) и гранулина вируса гранулеза (ВГ) A. segetum. Первичная структура полиэдрина нескольких ВЯП выяснена нами ранее [2--4]. Полиэдрины представляют собой группу высокогомологичных по первичной структуре белков, степень гомологии которых лежит в пределах 82 $94 \%$ [5]. Настоящее сообщение является первой публикацией по исследованию первичной структуры гранулина бакуловирусов.

Восстановленный и карбоксиметилированный гранулин расшепляли трипсином и химотрипсином. Методами гель-фильтрования, ионообменной хроматографии на $\mathrm{AG}-50 \mathrm{X}$ $X 8$, высоковольтным электрофорезом и хроматографией на бумаге, описанными нами ранее [3, 4], было получено 22 триптических и 34 химотриптических пептида. $\mathrm{N}$-концевую последовательность пептидов определяли методом Эдмана, как описано нами ранее $[3,4]$.

При сопоставлении триптических и химотриптических пептидов удается выписать 26 фрагментов с уникальной аминокислотной последовательностью, насчитывающих в сумме 212 остатков аминокислот, что составляет $91 \%$ полипептидной цепи белка с молекулярной массой 27500 [1].

1. Ser-Gly-Lys-GIu-Phe-Leu-Arg-Glu-Thr-Trp-Thr-Arg-Phe-Ile-Glx- $\Lambda$ sx-Glx-Phe-Val-

$\left(\right.$ Asx $_{2}$, Ser, Thr, Glx, Pro, Met, Leu, Tyr)

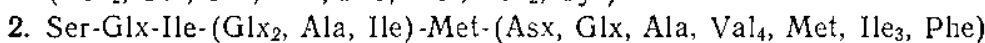


3. Tyr-Ala-Leu-Gly-Ala-His-Val-Asx-(His, Pro, Ala, Tyr)-Asp-Val-Ile-Arg

4. Ile-(Asx 2 , Thr, Ser, Glx 4 , Pro, Met, Leu, Phe)-Arg

5. Gly-Tyr-Trp-Tyr-Pro-Ala-Leu-(Thr ${ }_{2}$, Glu)-Arg

6. Ser-Leu-Asx-Val-Leu-Ile-(Lys, His, Asx)-Tyr

7. Lys-Gly-Tyr-Lys-Asn-(Ser, Gln, Glu, Ala, Ile)

8. Lys-Asp-Arg-Arg-Ile-Ser-Glu-Ala-Tyr

9. Phe-Asp-Glu-His-Leu-Pro-Tyr-Trp

10. Ile-Thr-Leu-Phe-Lys-Glu-Ile-Arg

11. Ser-Val-Tyr-Asx-(Asx, Glx, Phe)-Phe

12. Gly-Pro-Gly-(His, Pro, Gly)-Lys

13. Lys-Leu-Ile-Thr-Asp-Glu-Arg

14. Gly-Pro-Gly-(Lys, Asn, Ser)

15. Asx-Leu-Ala-Asx-Glx-Tyr

16. Phe-Thr-Gly-Pro-Ala-Tyr

17. Lys-Ile-Lys-Glu-Phe

18. Ile-Asn-Leu-Ser-Lys

19. Tyr-Ala-Pro-Leu-Lys

20. Thr-Cys-Leu-Gln

21. Ser-Leu-Tyr-Arg

22. Asn-Val-Arg

23. Leu-Glu-Phe

24. Arg-Leu-Tyr

25. (Arg, Pro, Leu)

26. Asn-Lys

Для полиэдрина ряда бакуловирусов сопоставление структуры только триптических пептидов с аминокислотной последовательностью полиэдрина ВЯГ Bombyx mori [2] позволяет реконструировать всю полипептидную цепь [5]. В случае же гранулина ВГ $A$. segetum не удается таким путем реконструировать первичную структуру белка. Очевидно, цто степень гомологии гранулина и полиэдринов значительно ниже гомологии, наблюдаемой среди полиэдринов.

\section{THE AMINO ACID SEQUENCE OF POLYPEPTIDE CHAIN FRAGMENTS OF THE AGROTIS SEGETUM GRANULOSIS VIRUS GRANULIN}

\section{E. A. Kozlov, T. L. Levitina, N. V. Rodnin, V. M. Kharchenko, S. B. Serebryany}

Institute of Molecular Biology and Genetics, Academy of Sciences of the Ukrainian SSR, Kiev

$\mathrm{Sum} \mathrm{m}$ a ry

The amino acid sequence of polypeptide chain fragments of the $A$. segetum granulosis virus granulin is presented. 26 fragments comprise 212 amino acid residues and account for $91 \%$ of the granulin polypeptide chain.

1. Некоторые физико-химические свойства белка тел включений вируса ядерного полиэлроза и вируса гранулеза озимой совки Agrotis segetum/Э. А. Козлов, Т. Л. Левитила, Н. М. Гусак, С. Б. Серебряный.-Бнополимеры и клетка, 1985, 1, № 3, c. $121-124$.

2. Реконструкция полипептидной цепи белка тел включений вируса ядерного полиэдроза тутового шелкопряда. Полная аминокислотная последовательность / Э. А. Козлов, Т. Л. Левитина, М. С. Кацман и др.-Биоорган. химия, 1978, 4, № 8, с. $1048-$ 1053.

3. Триптические пептиды белка тел включений вируса ядерного полиэдроза непарного шелкопряда / Т. Л. Левитина, Э. А. Козлов, М. Н. Овандер, С. Б. Серебряный.- Биоорганl. химия, 1981, 7 , № 7 , с. $985-995$.

4. Триптические пептиды белка тел включений вируса ядерного полиэдроза большой воцииной моли / Н. М. Гусак, Э. А. Козлов, М. Н. Овандер, С. Б. Серебряный.- Биоорган. химия, 1981,7, № 7 , с. $996-1007$.

5. Сравнение аминокислотной последовательности белков тел включений вирусов ядерного полиэдроза тутового, непарного шелкопрядов и большой вощинной моли / Э. А. Козлов, Т. Л. Левитина, Н. М. Гусак и др.- Биоорган. химия, 1981, 7, № 7, c. $1008-1015$.

Институт молекулярной биологии и генетнки

Получено 26.12 .84

АН УССР, Киев

БИОПОЛИМЕРЫ И КЛЕТКА, 1985, т. 1, № 3 